\title{
COVID-19 and resilience through Integral Mission: The impact of Social Enablement as Mission in previously disadvantaged communities in South Africa during the COVID-19 disaster
}

\section{Authors: \\ Phillipus J. Buys ${ }^{1}$ (1) \\ Jane M. Korevaar ${ }^{2}$ (1) \\ Guy R. Stubbs ${ }^{3}$ (1) \\ Affiliations: \\ ${ }^{1}$ School for Ecclesiastical \\ Science, Faculty of Theology, \\ North-West University, \\ Potchefstroom, South Africa \\ ${ }^{2}$ Management and \\ Administration, \\ Reformational Study Centre, \\ Kameeldrift, Pretoria, \\ South Africa \\ ${ }^{3}$ Khanyisani Trust, Centurion, South Africa}

Corresponding author:

Phillipus Buys,

buys.flip@gmail.com

Dates:

Received: 27 July 2020

Accepted: 19 Oct. 2020

Published: 17 Dec. 2020

How to cite this article:

Buys, P.J., Korevaar, J.M. \&

Stubbs, G.R., 2020, 'COVID-19

and resilience through

Integral Mission: The impact

of Social Enablement as

Mission in previously

disadvantaged communities

in South Africa during the

COVID-19 disaster', In die

Skriflig 54(1), a2663. https://

doi.org/10.4102/ids.

v54i1.2663

\section{Copyright:}

(C) 2020. The Authors. Licensee: AOSIS. This work

is licensed under the

Creative Commons

Attribution License.

Read online:

Scan this $Q R$ code with your smart phone or mobile device to read online.
The COVID-19 Coronavirus pandemic is seen as the most severe global disaster in history since the Second World War. How do two similar previously disadvantaged communities respond to the COVID-19 pandemic disaster? In the uMfolozi, community in KwaZulu-Natal, an intensive integral mission project through social enablement has been piloted during the past five years. In the Thembalethu community in Kwamhlanga, Mpumalanga, Social Enablement as Mission was about to be started when COVID-19 and, subsequently, the lockdown struck South Africa. This article summarises the key missiological and sociological principles of integral mission being done through Social Enablement and then compares and reflects on the response of 100 households in each of the communities on how they are handling the COVID-19 disaster. The article evaluates the developing resilience against disasters such as the COVID-19 pandemic that Social Enablement as Integral Mission has had on the uMfolozi community and compares it with the Thembalethu community. Finally, some recommendations are suggested on how to strengthen the resilience of people living in previously disadvantaged and poor communities through Social Development as a vital aspect of Integral Mission.

Keywords: Integral Mission; Social Enablement as Mission; COVID-19 disaster; coronavirus; Asset Based Community Development (ABCD); community development.

\section{Introduction COVID-19 disaster}

The United Nations Secretary-General, Antonio Guterres, described the Covid-19 pandemic as much more than a health crisis; he describes it as a 'human crisis' that is causing 'social and economic devastation' (Lederer 2020).

When comparing the Spanish Flu of 1918 and the Black Death of 1347 to COVID-19, a lot of similarities can be observed. Comparable to today's international travellers, the pandemics were spread by people (troops) being transported around the world during wars (Qureshi 2016:2-3). The viruses mutated into different strains. People living and working in close proximity to each other were affected the most, and the pandemics were spread by social contact.

During the Spanish Flu, 500 million people or one-third of the world's population became infected with this virus, and at least 50 million people died worldwide (Centers for Disease Control and Prevention 2020). The Black Death of 1347, where the equivalent of one-quarter of the total population of Europe (25 million people) died (Gould \& Pyle 1896:893), is perhaps a foreshadowing of what can be expected from COVID-19. South African newspapers are already predicting that the 'Covid-19 death storm is here' (Mkize, Masuabi \& Ntsaluba 2020:n.p.). On top of this, the impact on the economy has come at a devastating economic cost and breakdown of mankind's moral fibre. Promises have been made in South Africa such as the supply of food parcels and larger social grants to a selection of the population (Jeffery 2020:5). ${ }^{1}$ Before COVID-19 struck South Africa, $54 \%$ of the population was already in danger of hunger. The lockdown and resulting economic crisis have thus far had a far greater impact on a population where a third of the population spend half of their income on food (Stats SA 2011). Mark Heywood (2020:n.p.), a South African activist, quotes a University of Johannesburg/Human Sciences Research Council

1. By the time the surveys in this study were done (mid-June 2020), contrary to promises made by the government, not one of the 200 households surveyed had received a food parcel from government. To make matters worse, government have decided not to hand out food parcels, but rather increase social grants and thereby escalating dependency. 
survey where ' $34 \%$ of the people surveyed between 18 to 27 April [2020] reported that they had gone to bed hungry (up by $6 \%$ from an earlier survey)'. Respondents claimed that 'the worst things about the lockdown' were primarily a lack of income and hunger. Heywood (2020) also refers to a statement made by Professor Glenda Gray, a South African physician, scientist and activist specialising in the care of children:

We are seeing children with malnutrition for the first time [at Chris Hani Baragwanath Academic Hospital]. We have not seen malnutrition for decades and so we are seeing it for the first time in the hospital. (n.p.)

The National lockdown has worked well in prolonging the upward spiral of the pandemic, but at the same time it has created even greater and probably longer-lasting challenges that will have a negative impact long after lockdown has ended (Morifi 2020), and now the fast upward spiral of the pandemic curve seems to have arrived (Mkize et al. 2020). On top of the pandemic, economic, climate change, corruption, dependency on hand-outs issues (Granlund \& Hochfeld 2020:1230-1244) and broken prosperity-gospel promises (Mbewe 2013), poor people are left feeling helpless (Corbett \& Fikkert 2014a: Session 1).

\section{Problem statement Worldview and poverty}

Although the method of Social Enablement as Mission has been relatively successful in alleviating physical poverty in the uMfolozi community, as analysed in a study of Stubbs (2020), the researchers wished to evaluate whether Social Enablement as Mission could contribute towards developing a culture of resilience during the COVID-19 crisis.

Worldview was identified as an impacting issue to be assessed. Many researchers (Corbett \& Fikkert 2014a: Session 1; Laininen 2019:161-200; Miller \& Guthrie 2001:53-74) identified worldview as one of the main underlying causes of poverty and a lack of resilience. In his research on poverty in Africa, Van Rooy (1999) went as far as suggesting the following:

If all other factors change for the better, and this factor of an unbiblical worldview does not change, Africa will remain chained in poverty. On the other hand, if none of the other factors change, but this one factor does change radically, Africa can become a shining example of freedom from poverty. (p. 251)

In their short film series 'Reconsidering the meaning of poverty', Corbett and Fikkert (2014a: Session 1) point out the following biblical principles:

- People were made in the image of God, and therefore all people are important.

- All people need to understand that they are seen equally sinful by God, regardless of how materially wealthy or poor they are.
- Poverty is a result of broken relationships between us and God, us and ourselves, us and others and us and the environment, which are the results of the Fall (Gen 3).

- It is God's mission (revealed in the Bible) that God, through Jesus Christ, is busy restoring those relationships.

- We therefore, perform good works 'so that with our whole life we may show ourselves thankful to God for his benefits, and he may be praised by us' (Heidelberg Catechism 2015:Q/A 32).

In both communities that were surveyed, ${ }^{2}$ worldview plays a critical role in how poor rural households respond to poverty, transformation, stewardship, mentorship, crisis and resilience as in many other African communities (Corbett \& Fikkert 2014a: Session 1; Georges 2016; Magezi 2007; Mbiti 1969, 1970; Mbuvi 2002; Miller \& Guthrie 2001; Nyirongo 1997; Setiloane 1986; Turaki 1999; Van der Walt 1999). Some of the aspects of a worldview that prevent poor people from breaking free from a cycle of poverty include:

- Dependency on things or people rather than God: Altogether $20 \%$ of poor South Africans rely on social grants (Webb \& Vally 2020). Their focus is on maintaining the assurance of receiving these grants; so, they focus on an animistic, syncretistic, prosperity gospel or secular belief systems that hope in receiving relief from someone, something, a kind of deity, or a magical genie kind of god (Awendila 2020). For this reason, they often feel helpless because of their poverty (Corbett \& Fikkert 2012; Johnson 2012; Reese 2012; Schwartz 2007), especially during a crisis (Granlund \& Hochfeld 2020:1230-1244).

- A distorted understanding of God: John Calvin upheld that sensus divinitatis [sense of divinity] exists with all mankind (Helm 1998:87-107). But this sense of divinity is distorted in an animistic, syncretistic prosperity gospel and secular belief systems, because there is a lack of a valid biblical understanding and conviction of who God really is and what his attributes are (Van Rooy 1999:235). Often God is seen as merely a provider or simply another source of good luck.

- Conditioned hopelessness: Often poor South Africans do not have or are fearful of having the initiative to develop progress because of the beliefs they live by (Corbett \& Fikkert 2012; Georges 2016; Magezi 2007; Mbetwa 2018; Mbiti 1969; 1970; Mbuvi 2002; Nyirongo 1997; Setiloane 1986; Turaki 1999; Van der Walt 1999). In his book, Choolwe Mbetwa (2018) suggests a few faithbased traits among rural people living in Southern Africa:

- 'Hierarchism' - a power management system that prioritises patrilocal and unconditional hierarchical respect and fear (with ancestral veneration central in the hierarchy) that can be manipulated by self-centred 'authority bullies' that people become enslaved to.

- 'Communalism' - a positive attribute that becomes destructive when it destroys individual responsibility and incites an expectation of false entitlement, tribalism and xenophobic attitudes. 2.The survey was not done among children. Thus, the findings do not rely on any
interviews with children, but only adults and is based on a mixed research methodology. 
- 'Traditionalism' - unconditional upholding or maintenance of tradition that resists change that is needed (Lumumba 2013; Marumo 2016:9-11).

- A weak understanding of the gospel message: The futurist, Sumit Paul-Choudhury (2019), claims that, although faith in an animistic, syncretistic prosperity gospel or secular beliefs results in social cohesion, Zaspel (2020:2) and Van Rooy (1999:235-240) argue that they are unpromising and fatalistic in comparison to how free the gospel is for sinners. On an African understanding of the gospel message, Van der Walt (1991) suggests that the average African 'convert' is not helped to

$[E]$ xperience the gospel as adequate for the whole life of an individual and transformation of communities. For that reason, we get the phenomenon all over Africa today that Christians, in time of need and crises, (such as illness or death) often revert to their traditional faith. (p. 125)

The result is that 'the core of the African culture remains untouched' (Van der Walt 1991) and only a veneer of Christianity is embraced (Mathema 2007:6).

- A lack of understanding Christian stewardship: Human dominion over the rest of creation is to be an exercise of kingship that reflects God's own kingship. Wright (2010) reminds us that:

[T] he image of God is not a license for arrogant abuse, [or laziness as described in 2 Th 3:1: those who do not work shall not eat], but a pattern that commits us to a humble reflection of the character of God. (p. 51; cf. Van der Walt 2003:450)

- Inappropriate development and training of Christian leaders: Although $80 \%$ of South Africans are confessing Christians (Stats SA 2004:25-28), the majority have faith in the prosperity gospel, because the only theological training accessible to many pastors is prosperity gospel on television (Somdyala 2019). When there is a misunderstanding of the gospel of Jesus Christ, people become disillusioned; they cannot discern between physical wealth and health, and spiritual riches (Somdyala 2019; Van Biema \& Chu 2006). Conrad Mbewe (2013:n.p.) describes the witchcraft practices among some church leaders and then asks the alarming question: 'Are we pastors or are we witch doctors?' The lack of well-trained servant leaders in African churches prevent people from gaining dignity and becoming self-sufficient (Mbewe 2013:n.p.).

- Lack of biblical mentorship: Corbett and Fikkert (2014c: Session 6) and (Leshota 2015:4-8) propose that mentorship should foster 'interdependence' in comparison to dependence or independence. Poor people need a circle of support, they need social networks, they need to be helped to help themselves, and they should end up helping each other (Corbett \& Fikkert 2014b: Session 5).

\section{Biblical theological reflection on resilience}

Resilience can be defined as a process of adapting successfully in the context of a threatening situation (Germann 2005:42). Resilience enables people to muster considerable strength and capability to address their crises and meet their crises head-on. Riopel (2020) asserts that people who have survived a crisis, build up a resilience to crises, because they realised that they had made it through past crises.

In this article, resilience is understood from a Christian perspective which is not only the ability to bounce back from a crisis, but also to learn from an adverse experience to such an extent that the ability is gained to reach out to others in adverse experiences and comfort them to deal with their challenges (1 Cor 1:3-4).

\section{Resilience is described in 2 Corinthians 1 as:}

Blessed be the God and Father of our Lord Jesus Christ, the Father of mercies and God of all comfort, who comforts us in all our affliction, so that we may be able to comfort those who are in any affliction, with the comfort with which we ourselves are comforted by God. (vv. 3-4)

Christian resilience is built on a biblical understanding of hope. The lifestyle of the early Christians provides an amazing picture of how Spirit-filled Christians lived in the world. Rodney Stark's book, The Rise of Christianity (1996:167), reveals historical facts, but also brings a sociologist's perspective to bear on the puzzle behind the tremendous growth of early Christianity. He then pointed out with historical facts that there were three ways in which the early Christians remarkably radiated forms of resilience different from than their pagan neighbours:

- When the great epidemics hit the urban centres, while others just fled, Christians stayed to care for the sick and, in the process, several died while caring for their sick neighbours.

- Secondly, when Christians were persecuted, they did not respond with retaliation or guerrilla warfare, but they died while they were praying for their persecutors.

- Thirdly, when Rome conquered all the nations, all the national borders were opened. The cities became fiercely multi-ethnic, which lead to a great deal of ethnic tension. The Christian church was the first institution in the history of the world that brought people together across those ethnic barriers and declared that race means nothing.

You could ask yourself why the Christians were so much more compassionate to the sick. Why were they so much more forgiving to their persecutors? Why were they so much more ethnically inclusive than everybody has ever seen before? There is one main answer: Their attitudes and lifestyle were dependent on what they believed their ultimate future was going to be. Christians had hope in God's promises! They were shaped by a joyful certainty of God's great future: eternal glory and love. Therefore, they could stay in the cities, because they were not afraid of death. They knew after death comes a face-to-face experience of God's eternal love. The reason they did not retaliate against their persecutors with violence and terrorism is because they knew that, by the end of time, God would judge everything and make everything right. 
They were ethnically inclusive, because they believed that there was one God who was busy gathering his new people from every tribe, tongue and nation.

When the Holy Spirit takes hold of your life, He brings this supernatural joyful assurance of God's future glory in your life and you start to radiate Christ's compassion into this broken world. (Buys 2020)

Leslie Newbigin (2017), when asked to explain what a Christian is, used the following illustration:

When people were walking in an Eastern direction on the narrow mountain paths in the early morning a strange red light was shining from their faces. People who saw it asked with wonder and amazement: 'Why are their faces radiating such a brilliant light?' Later they then discovered it was the reflection of the rising sun shining from their faces. (n.p.)

Thus, a real Christian is someone who is walking towards the Sun of Righteousness, Jesus Christ, and his triumphant return to this world and therefore radiates the love of God back into the world around him. Paul's words in Romans $8: 18$, 'I consider that the sufferings of this present time are not worth comparing with the glory that is to be revealed to us', enables the Christian to be resilient.

\section{Social Enablement as a vital aspect of Integral Mission}

The method of Social Enablement as Mission is a form of social upliftment, or rather the enabling of social transformation by the Holy Spirit through proclamation and demonstration of the gospel message, and is a valid and relevant approach of evangelism and discipleship in rural South African contexts (Goheen 2011; Jansen 2017; Mashau 2012; Wright 2010).

When practised in a correct way, beneficiaries of the method experience the immediate and physical working out of the Holy Spirit (Goheen 2011:201-226). 'The Holy Spirit empowers Christians to live righteously, despite opposition, resulting in fruitful, productive lives' (Buys \& Stubbs 2019). The temporal and eternal hope that they experience, empowers resilience to life's problems and enable them to 'glorify God through work and service' (Fikkert \& Mask 2015:49). The focus of this model for Integral Mission is, 'Enabling people to realise that through God's transforming grace in Christ, they are capable to change their own lives.' In this way, members experience a foretaste of already participating in God's New Creation (Myers 1987:181; Wright 2008:25).

The African Honey Bee project is an example of integral mission that uses Social Enablement as Mission. Individuals are not disadvantaged by discrimination, but rather choose to join the project, because they realise that they can and want to change their own lives. This results in a demographic in which $85 \%$ of members are women, $10 \%$ are disabled and $65 \%$ are the youth. Thus, people with the least opportunities are enabled to access the opportunities that are available to them to transform their own lives - to use the gifts, talents and provision given to them by God. The focus during the self-selection process (and then throughout) is Asset-Based Community Development $(\mathrm{ABCD})^{3}$ where members are taught to use available 'provision by God' (their abilities, resources and relationships) to transform their own lives, the lives of their families and the lives of their community. When they realise through the working of the Spirit that God has provided all they need, and hope through faith alone, their perspective on life changes and one witnesses positive transformation.

Once a group of members (who meet at a venue within walking distance from their homes) has been formed, they are taken through several workshops in which they learn to establish their own self-help savings group. ${ }^{4}$ Firstly, at every meeting, they learn the basic biblical principles of Christian stewardship and how to save and manage their money corporately. By working together, they: (1) develop corporate and individual discipline; (2) gain access to lower business input costs; (3) access more reliable markets; (4) share logistics costs; and (5) access credit for starting additional income generation activities. Most importantly, they start interacting in a biblical way with each other from a Christian $u B u n t u^{5}$ perspective. They start seeing that biblical principles transform and develop resilience. Secondly, they are practically taught basic income generation principles, and how to apply these to their business ideas. Thirdly, they are taught and assisted to start 'business in a box' - a method of small-scale food production businesses designed around activities that many of them are already busy with such as honey harvesting, chicken meat and egg farming, and vegetable and fruit production. The difference though is that the methods taught are all Christian ABCD (realising that provision comes from God), climate-smart (biblical stewardship based) and replicable (evangelistic and discipleship based). Micro and social franchising principles are then applied to replicate, scale the project up and create value chain linkages.

\section{Evaluation methodology}

For this article, the researchers assessed the worldview of two similar groups of households in two similar South African communities in the way they responded to COVID-19. The first group was from uMfolozi in KwaZuluNatal where African Honey Bee has been developing the Social Enablement as Mission method over the last 5 years. The second was a group from Thembalethu in Mpumalanga where the Khanyisani Trust (administrator of the African

3.Asset-based community development (or ABCD) is founded on the idea that change will only happen if we identify and mobilise the gifts and capacities of local people and the social, physical and economic resources of a local place. It is an approach that seeks to build strong, sustainable communities from the "inside out", through forging and nurturing relationships of care and creativity' (Barrett 2013:1).

4.Tearfund defines self-help groups as a form of community-based approach to microfinance that in addition to economic activities attributes additional importance to the spiritual, social, human and political dimensions of diverse livelihoods that to the spiritual, social, human and political dimensions of diverse livelihoods that contribute to strengthen enhancing food security in times of increasing climate stress (Weingärtner, Pichon \&
Simonet 2017:12).

5.'I am because God is, and so we all are' (Stubbs 2020:124). 
Honey Bee project) planned to start a project called ChildVision that would use Social Enablement as Mission as part of Early Childhood Development helping to train 30 Orphan and Vulnerable Children Centre workers from six centres to run their centres more biblically, efficiently and sustainably by teaching them to uplift and involve the local community. This project was due to begin in April 2020, but was put on hold due to COVID-19 and lockdown. A 100 households who are part of the African Honey Bee programme in uMfolozi and 100 households in close proximity to and involved with Thembalethu Centre in Thembalethu were surveyed.

A questionnaire (Appendix 1) was developed by the researchers that asked several questions about how worldview influenced household responses to the COVID-19 crisis. The answers were recorded manually by eight facilitators, captured and rated electronically in the following way:

- Valid biblical answer - clearly mentioned salvation; Jesus Christ; God sent his only Son to die for our sins; praise; adoration or supplication to God. Some sample answers included the following: for people to believe in God; it is God's will; testing our faith; spiritual food; God's Word; guiding us through the Holy Spirit; cannot believe in both ancestral worship and God; cannot worship two gods at once; love your neighbour as yourself, because God gives us to share; believe God's promises; believe in God and he gives us hope; God has been with us through all our difficulties.

- Syncretistic answer - mentioned anything positive toward ancestral worship. Some sample answers are as follows: God is somewhat more powerful than man - an alternative to ancestors; it is written in the Bible that these issues such as the coronavirus is a form of witchcraft and spirits giving us bad luck.

- Secular answer - did not mention God at all. It is government related; man-made virus; virus affects us economically reasons; virus is part of a conspiracy theory. Other answers included the following: natural causes; don't help others; scared; we are to stay home.

- Animistic answer - mentioned evil spirits is testing us. God is far and unapproachable; we don't know what God thinks of us; we see God in many ways.

- Answers related to the prosperity gospel - without a gospel message. It indicates that God always loves us; God is never angry with us; prayer items are only for this life; all about me being a success; always being healthy; a successful life; God would never make us sick; God does not want us to die; God does not create a problem without a solution; God protects us from all enemies and sickness; God cannot destroy his creation; we are all children of God; God makes sure we wake up every day.

Once all the data was captured and rated, several pivot tables were created to compare the results. The information in this article is a selection from all that information.

\section{Community sample descriptions}

The respondents from the two sample communities were selected for the following reasons:

- Both groups of respondents were people living in extremely poor South African rural communities.

- As seen in Figure 1, both groups had similar socioeconomic profiles. One slight difference was that the households in Thembalethu were recorded to have approximately $9 \%$ more people with jobs than uMfolozi (Stats SA 2011).

- A 100 respondents representing 100 households from each area were selected to participate in the survey:

- In uMfolzi the respondent households had been part of the African Honey Bee project and exposed to the Social Enablement as Mission model for 5 years. Respondents, as can be seen in Table 1, were in the $30 \%$ bracket of households that earn less than R10 000 per year.

- In Thembalethu $30 \%$ of the respondent households were directly involved with the children at Thembalethu Orphan and Vulnerable Children Centre (caregivers or parents) and the rest were local households living in close proximity to the centre. None of them had been exposed to the Social Enablement as Mission model. Respondents, as can be seen in Table 1, were in the $29 \%$ bracket of households that earn less than R10 000 per year.
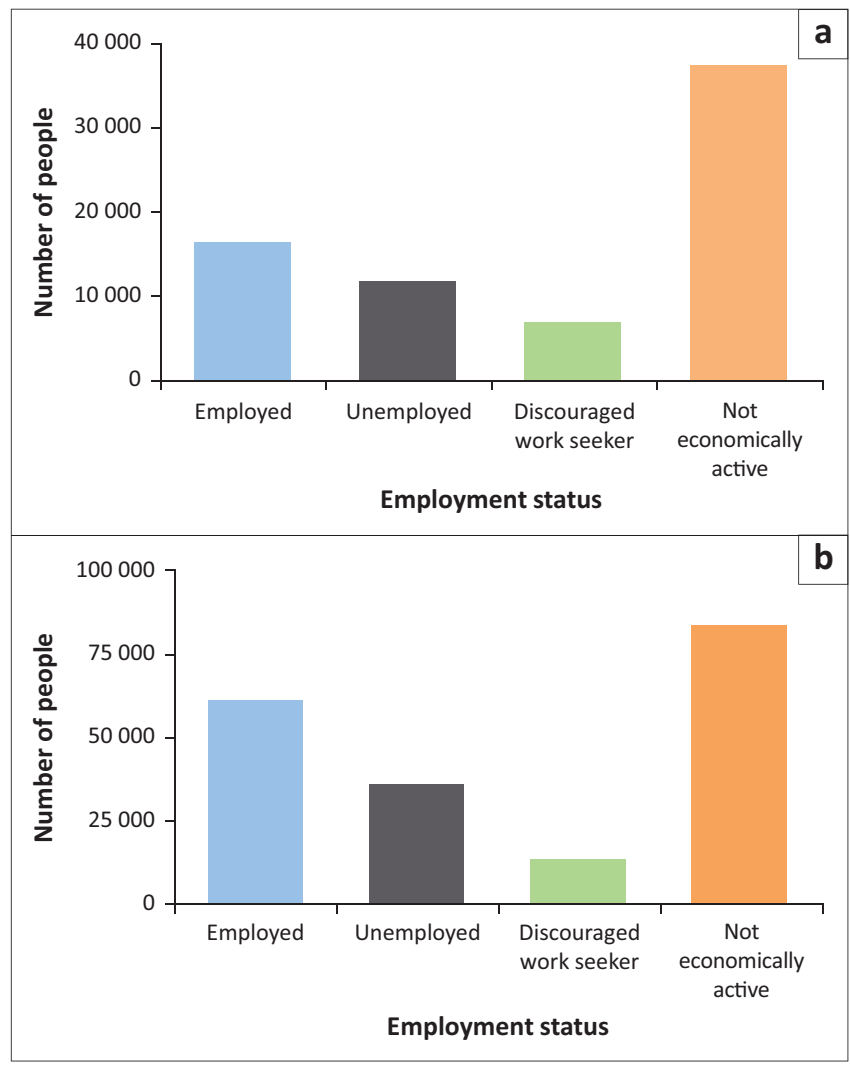

Source: Stats SA., 2011, Statistics South Africa, viewed 13 July 2020, from http://www. statssa.gov.za/

FIGURE 1: Economic profile comparisons: Employment for these aged 15-64 in: (a) uMfolozi and (b) Thembalethu. 
TABLE 1: Average household income comparison.

\begin{tabular}{lcc}
\hline $\begin{array}{l}\text { Average monthly/annual household } \\
\text { income comparison }\end{array}$ & Thembalethu (\%) & uMfolozi (\%) \\
\hline No income & 13.80 & 14.70 \\
R1-R4 800 & 5.60 & 5.50 \\
R4 801-R9 600 & 10.00 & 10.00 \\
R9 601-R19 600 & 20.30 & 22.90 \\
R19 601-R38 200 & 23.60 & 23.70 \\
R38 201-R76 400 & 15.20 & 12.60 \\
R76 401-R153 800 & 7.40 & 5.80 \\
R153 801-R307 600 & 2.90 & 2.80 \\
R307 601-R614 400 & 1.00 & 1.50 \\
R614 001-R1 228 800 & 0.20 & 0.30 \\
R1 228 801-R2 457 600 & 0.10 & 0.10 \\
R2 457 601+ & 0.10 & 0.10 \\
\hline
\end{tabular}

Source: Stats SA., 2011, Statistics South Africa, viewed 13 July 2020, from http://www. statssa.gov.za/

\section{Data analysis and reflection Number of people in household}

It was interesting to observe that the households surveyed in uMfolozi were larger by $36 \%$. Where 574 people live in the 100 surveyed households in Thembalethu, 902 people live in the 100 surveyed households in uMfolozi (Figure 2).

Stats SA (2004) publishes that the average household size in uMfolozi is made up of 4,7 people. The average from this survey was nine people per household, indicating that the average income per person among the surveyed households in uMfolozi is less than R3 (\$0.18) per day. In Thembalethu, the official household size is 4.6 (Stats SA 2004) and the average from this survey was 5,74 people, that is, income per person is less than R5 (\$0.30) per day. These figures are shocking when one considers that the figures from uMfolozi are $9 \%$ and Thembalethu $15 \%$ of the globally accepted yardstick of less than $\$ 2$ per day for extreme poverty. Fikkert and Mask (2015:55) state that there are globally '2.6 billion people living on less than $\$ 2$ per day'.

\section{Age graph}

The average age of all 200 respondents was 42.49 years, $41 \%$ were male, while $59 \%$ were female.

\section{Jobs vs Income generation}

The researchers distinguished the difference between 'jobs' and 'income generation' in the following way: Jobs were regarded as work that individuals in the respondent households might have where the person earns a salary. Social grants were largely (65\%) regarded as compensation for voting (Patel et al. 2014:4), and income generation was regarded as additional income derived from entrepreneurial activity.

If one calculates the unemployment in each area in comparison to the number of people, the figures are very concerning: uMfolozi $91 \%$ and Thembalethu $88 \%$. One can see the correlation of these figures when compared to the number of social grants received by the two sample communities where $88 \%$ of the respondent population in

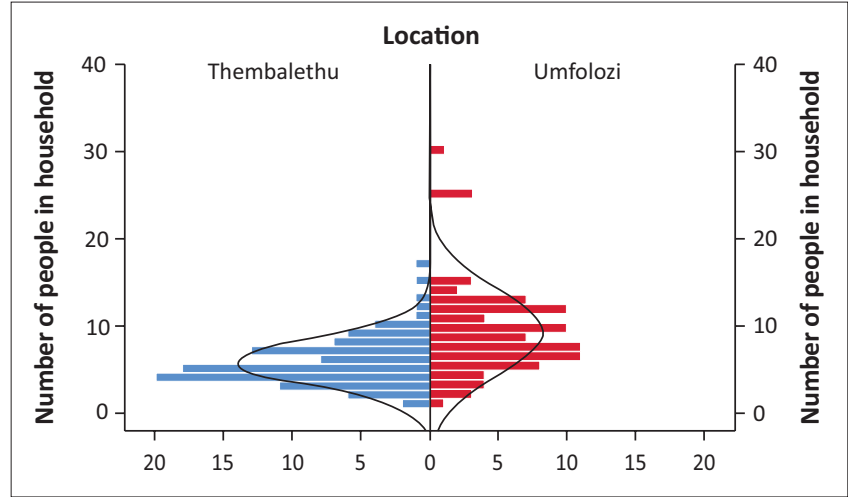

FIGURE 2: Number of people in households comparison.

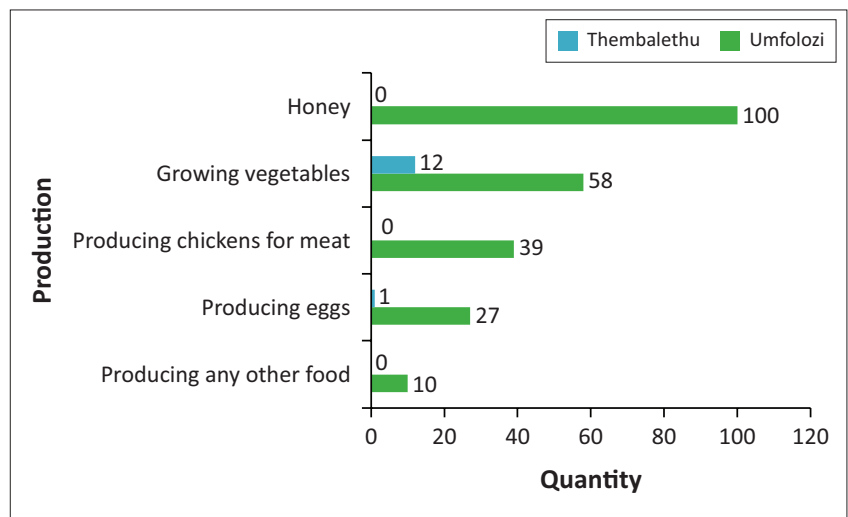

FIGURE 3: Food production comparison.

uMfolozi receive social grants compared to $85 \%$ in Thembalethu.

Conversely, the number of jobs correspond as $8 \%$ for Thembalethu and $6 \%$ for uMfolozi. Out of these $5 \%$ lost their jobs due to COVID-19 in Thembalethu and 1\% in uMfolozi. Noteworthy, none of the 200 respondents received food parcels from government, but all who were registered on the government social grant scheme received the additional COVID-19 social grant from June 2020.

On the positive side, in uMfolozi, $100 \%$ of the households were involved in income generation activities. This is probably the most distinguishing factor, especially when compared to Thembalethu where only $1 \%$ of the households were involved in income generation. The figures were also swayed due to the fact that $100 \%$ of the uMfolozi households were involved in honey production.

\section{Food production}

If one takes honey production out of the equation, $58 \%$ of the uMfolozi households were involved in food production (58 produce vegetables, 39 meat from chickens, 27 eggs, 10 other), in comparison to Thembalethu where only $12 \%$ were producing additional food (12 produce vegetables and 1 egg) (see Figure 3).

\section{The Bible is the Word of God}

Of the 200 respondents $98 \%$ of the 200 respondents believed that the Bible is the Word of God. 


\section{The main message of the Bible}

Interestingly, in Figures 4 and 5, animism was the lowest answer for both respondent communities with a maximum of $2.06 \%$ for Thembalethu. With prosperitygospel answers, uMfolozi was almost at the same level as syncretistic for Thembalethu. Although prosperity-gospel answers were more in uMfolozi, when the results for prosperity gospel were combined with the biblical answers, the number in uMfolozi (62\%) was almost double that of Thembalethu (37\%). This could be significant when one considers that, although prosperitygospel answers did not mention the gospel message, they were not unbiblical.

To get a clearer picture of how the respondents reacted to the prosperity gospel answer, an interesting picture showing the similarity between the two communities evolved (below in Figure 6) and highlighted the extent of the problem in rural South Africa. The most striking result was what the respondents pray about, which was mostly self-centred rather than God-centred. This indicated to the researchers that there is a lack of understanding of who God is, his attributes, and who the respondents are in comparison, and the nature of a relationship with the LORD God.

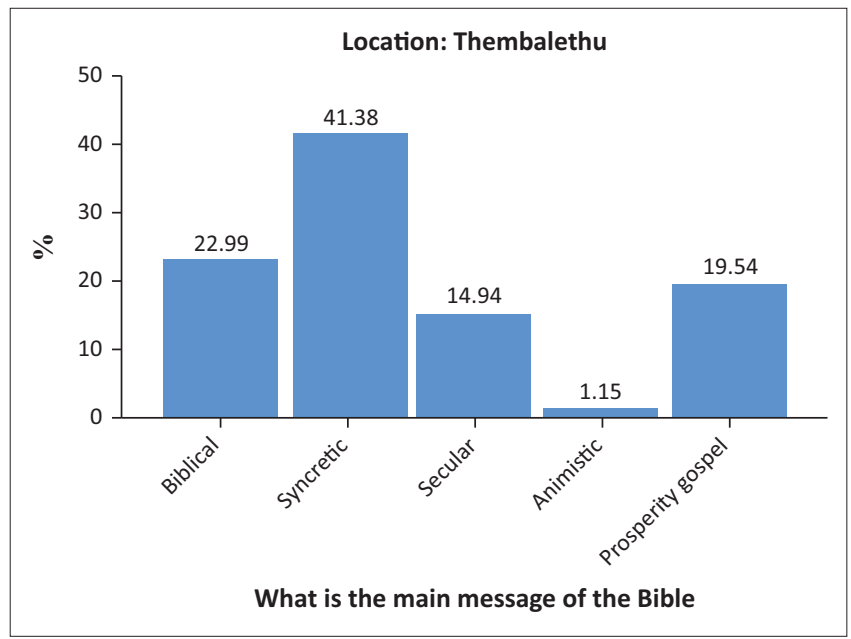

FIGURE 4: Thembalethu Bible message worldview comparison.

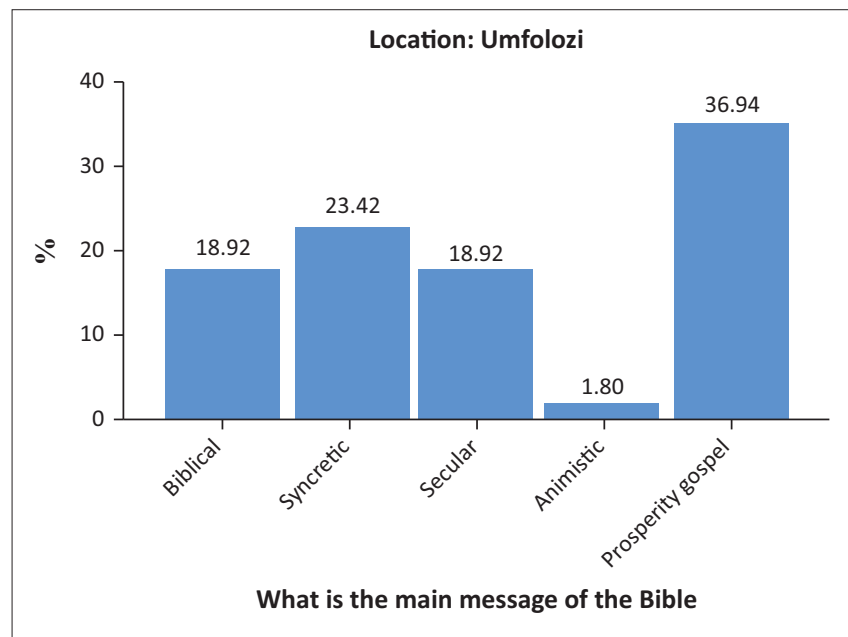

FIGURE 5: uMfolozi Bible message worldview comparison.

\section{Do you pray?}

Out of 200 respondents, 198 answered that they pray and 192 of the 200 said that they pray about COVID-19 (Figure 7). Interestingly, $85 \%$ of respondents answered that they pray for prosperity-gospel-related blessings.

\section{Do you think God sent the coronavirus?}

The response was almost equal in both locations with $41.5 \%$ answering yes. The researchers interpret this as a syncretistic or prosperity gospel conviction.

\section{Explanation for 'Do you think God sent the coronavirus?'}

In Figure 8 the prosperity gospel received the most answers $(43 \%)$ followed by syncretistic answers (25\%). The answers were almost equal for uMfolozi and Thembalethu for prosperity-gospel and syncretistic answers.

\section{How do you think God works to care and provide for us today?}

Both respondent groups gave similar and prosperity-gospeldominated answers.

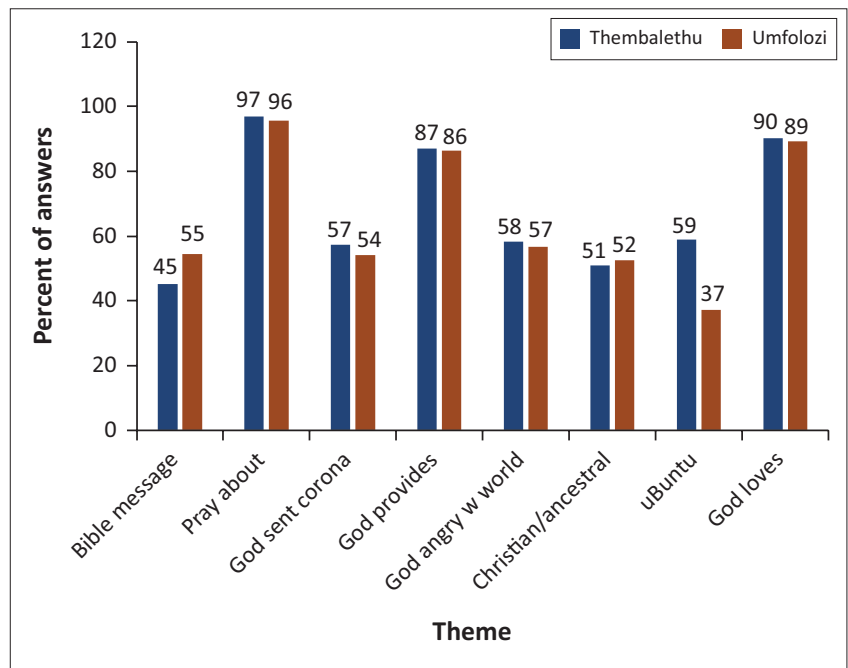

FIGURE 6: Prosperity gospel theme comparison: Total biblical and prosperity gospel answer comparison.

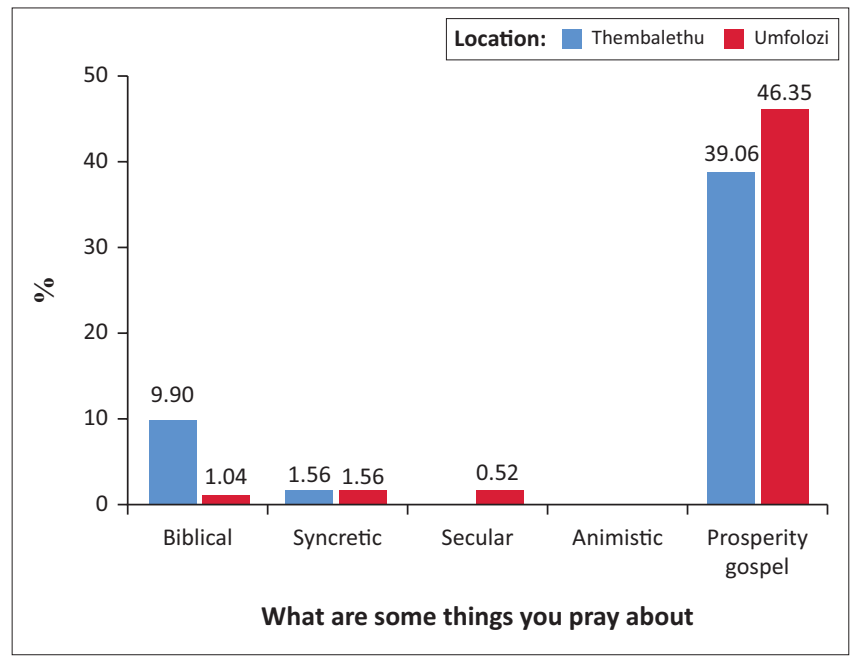

FIGURE 7: Prayer topic worldview comparison. 


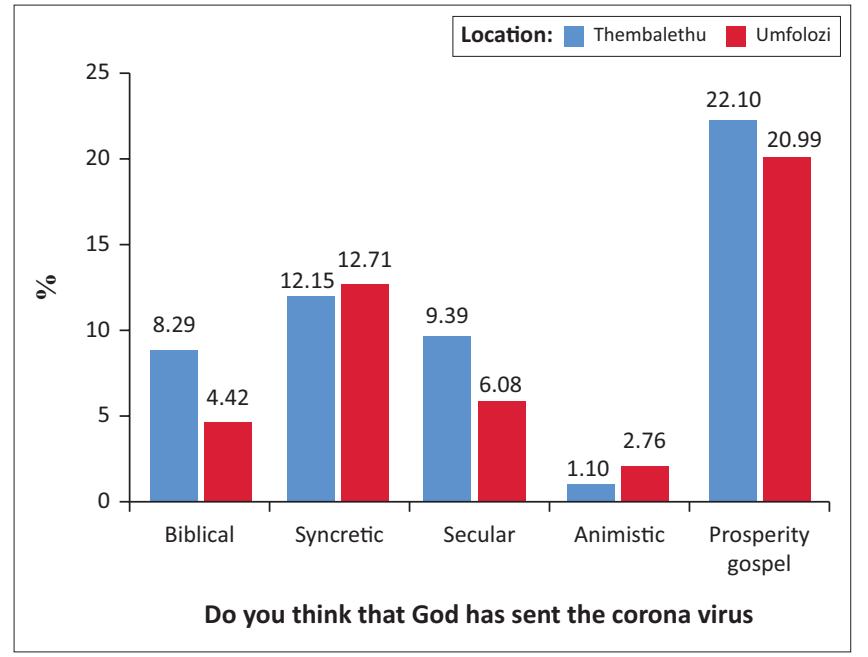

FIGURE 8: God as the cause for COVID-19 worldview comparison.

\section{Can we be sure that God loves and cares for us?}

Figure 9 illustrates the answer to this question, which were mostly prosperity gospel and biblical with more biblical answers coming from uMfolozi.

\section{Do you believe that you can be a Christian and also believe in ancestral spirits?}

This answer reflected how syncretism ${ }^{6}$ is a big problem among both respondent communities. Thembalethu, however, does seem to have a slightly greater problem. It is not clear (as in the reduced animistic results) whether this was due to the interventions of Social Enablement as Mission (Figure 10).

\section{Healing ability of traditional healers}

This response was interesting from the perspective that, even though other answers show less reliance on an animistic and syncretistic worldview (Figure 11), when it comes down to critical issues, syncretism is still a big problem in both communities.

\section{Traditional healers can cure coronavirus}

Although, in the previous figure we saw a similar response to syncretism from both respondent communities, in Figure 12 there seems to be a growing lack of confidence in an animistic worldview, especially by the uMfolozi community. One would hope that this is also due to Social Enablement as Mission.

6.The word syncretism is used in the same way it is being used by well-recognised evangelical African scholars such as Yusufu Turaki (2012), and Leonard Nyirongo (1997)

The article focuses on the problem of inappropriate syncretism in some Christian communities in Africa (without the researchers implying that there are no exceptions) stemming from a lack of spiritual maturity. Inappropriate syncretism is not only a sign of spiritual immaturity - sometimes of no conversion, but also stunts Christian growth, responsible stewardship and poverty alleviation. The article's goal is to propose a solution to this problem.

The article argues that the idea of adaptation should be replaced by the idea of transformation in the light of God's Word.

In line with several evangelical African scholars the article holds to the view that a spiritual reformation that produces mature, evangelical Christians is vital to achieving the goals of the African Renaissance, as it restores the African identity achieving the goals of the African Renaissance, as it restores the African identity and African customs (those compatible in a valid way with biblical Christianity) lifts African humanity to greater heights, fulfils the longings and dreams implicit in ATR, provides the spiritual and moral fibre Africa needs, and strengthen democracy - all of which are key to development so desperately needed in Africa.

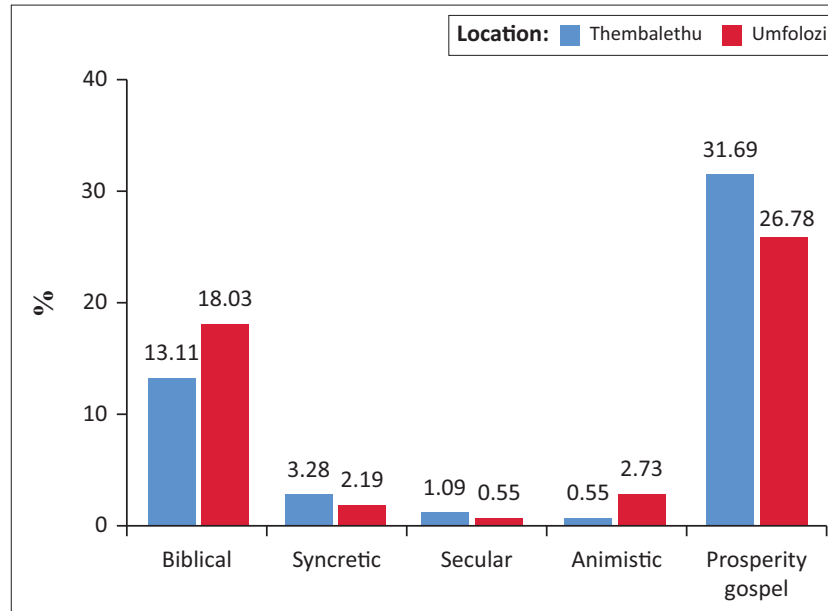

How can we be sure that God loves and cares for us

FIGURE 9: God loves and cares for us worldview comparison.

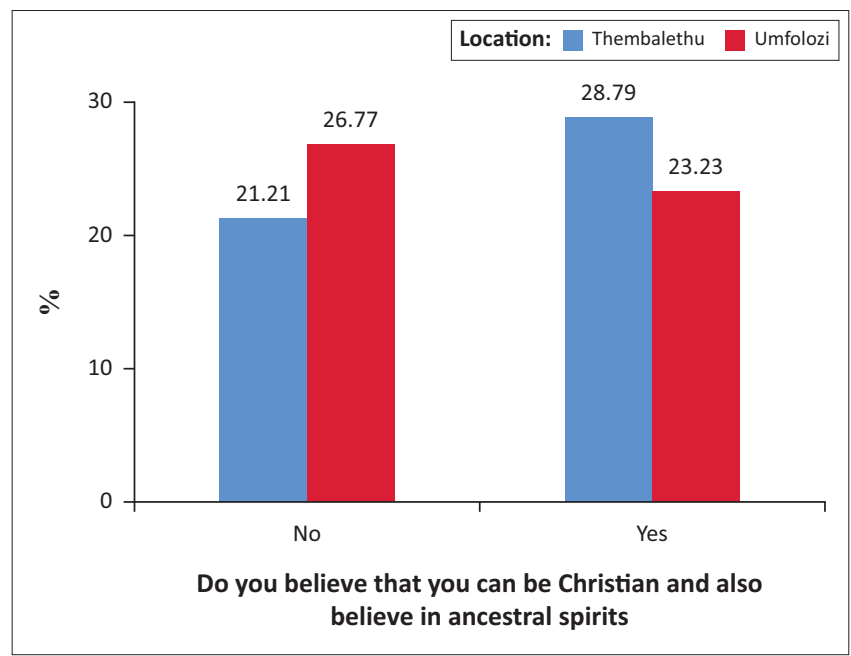

FIGURE 10: Syncretism worldview comparison.

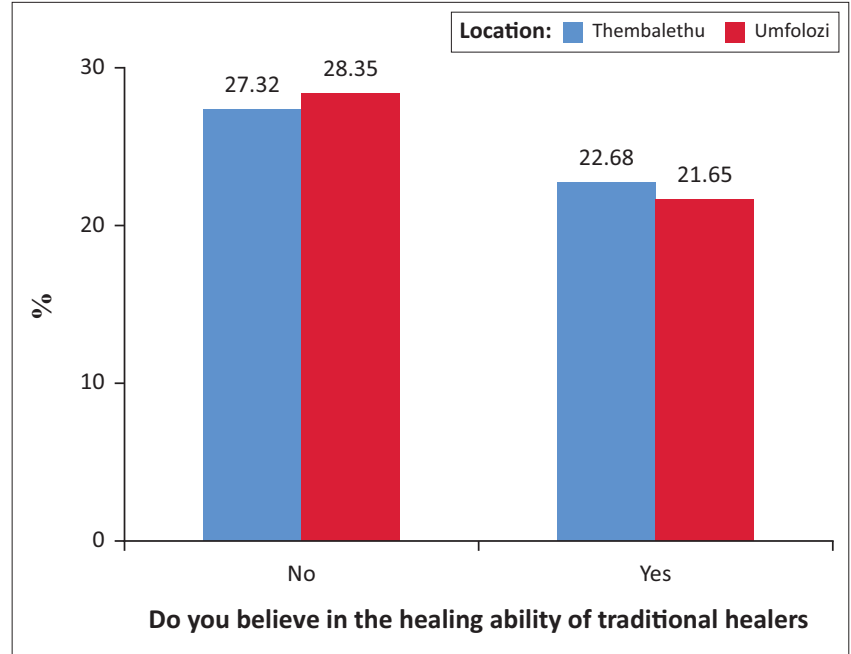

FIGURE 11: Healing ability of traditional healers' worldview comparison.

\section{Do you think social distancing can stop the spread of the coronavirus?}

Most respondents (93\%) answered yes to this question, indicating that the government is effectively communicating COVID-19 safety protocol. 


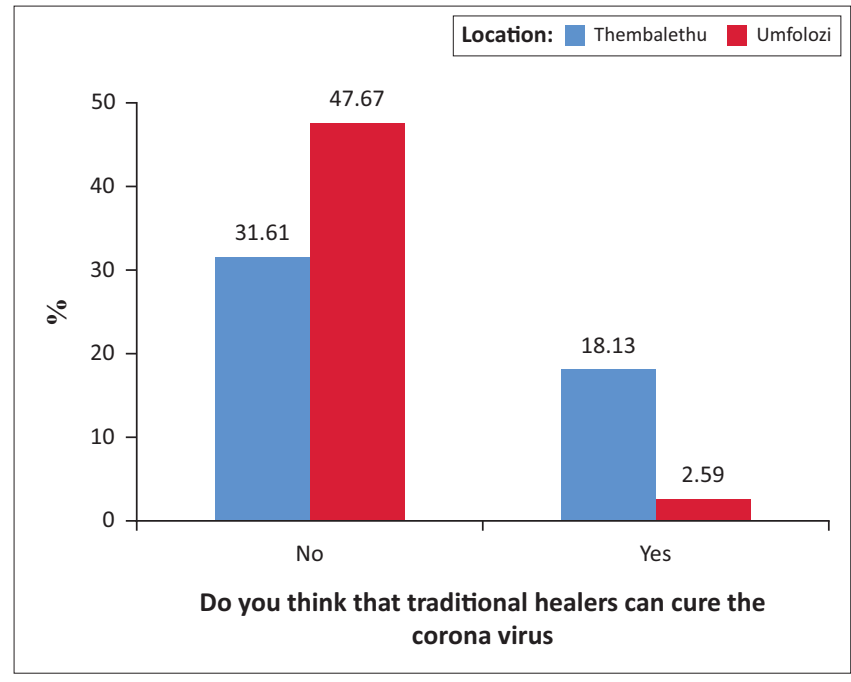

FIGURE 12: Traditional healers cure COVID-19 worldview comparison.

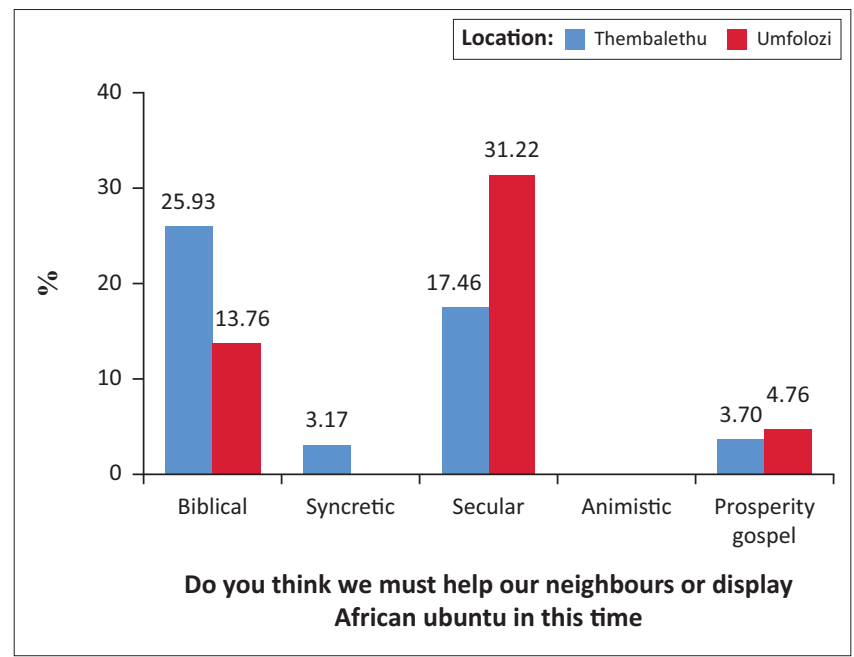

FIGURE 13: African uBuntu worldview comparison.

\section{What is the motivation for social distancing?}

This question was asked to measure concern (Christian love or $u$ Buntu) for others. The researchers think that the answers to this question $(97 \%$ of all respondents answered that they did not want to spread the virus) highlight the positive aspects of communalism found in the African culture and government's success in communicating COVID-19 safety protocols.

\section{Do you think we must help our neighbours display African uBuntu in this time?}

Once again it was positive to see that the $87.5 \%$ of the respondents who replied yes, reflect a Christian love or uBuntu for others. In Figure 13 below, one can see how respondents from Thembalethu interpreted $u B u n t u$ more from a Christian love perspective to the uMfolozi respondents who understood $u$ Buntu more from a secular ideological perspective.

\section{Discussion of analysis}

While conducting the survey, the researchers were greatly encouraged, on one hand, by the fact that they were welcomed by a hive of activity in uMfolozi where participants in the project were busy harvesting honey, growing vegetables, producing eggs and poultry. Households were proud to show them what they were growing, producing, selling and saving. On the other hand, it was such a contrast to the visit that they had to Thembalethu where respondents seemed to radiate much more dependency and a sense of entitlement attitudes towards the government. The greetings were from families who were all asking for financial assistance of some kind.

When analysing the data, a couple of trends emerged:

- The method of Social Enablement as Mission was working well from income generation perspective, but the results for a biblical outlook on life was disappointing, especially if prosperity gospel was not included in the measurement. In other words, although Thembalethu seems to have a greater syncretism problem than uMfolozi, it also has a better grasp of the gospel message.

- As explained earlier, prosperity-gospel answers were not necessarily biblically untrue; they just did not make mention of the gospel message. So, if the prosperity gospel and biblical answers are combined, uMfolozi theoretically could have a better understanding of Christian principles.

- Another assumption that came out of the uMfolozi survey and visit to the communities was that Social Enablement as Mission could be the impetus that ultimately spurred project members to radiate Christian stewardship both in using the gifts given to them by God (by producing food for themselves and generating income) and in helping their families and communities (through the self-help savings groups), and thereby enabling them to be more resilient to the COVID-19 crisis.

- Overall, in both groups, respondents were very religious. The majority said that they were Christian.

- Animism was very low compared even to syncretism.

- A high response rate of the prosperity-gospel and syncretism worldview answers indicated a lack of access to biblical instruction and mentorship.

- Income generation was seen differently to a job or social grants. Income generation was regarded as income derived from entrepreneurial activity.

\section{Conclusion}

In uMfolozi, Social Enablement as Mission seems to have been successful, because the families, surveyed for this article, have shown that they are able to adapt successfully in the context of a threatening situation (Germann 2005:42). They had developed ways to produce food and generate income. But if a Christian definition of resilience is considered, as quoted below, success is questionable:

[N]ot only the ability to bounce back from a crisis but also to learn from an adverse experience to such an extent, that the ability is gained to reach out to others in adverse experiences and comfort them to deal with their challenges (1 Cor 1:3-4).

As seen from the empirical research, the uMfolozi respondents lean towards a prosperity-gospel and a syncretistic 
worldview. This lack of gospel understanding and a concern for self (deduced from the answers listed in the section titled 'Community sample descriptions' and measured in Figures 4-12 above), indicates that there is an insufficiency of biblical training and mentorship in the Social Enablement as Mission model of integral mission. Our final conclusions are the following:

- In social development, the gospel message needs to be proclaimed and demonstrated.

- For social development to be sustainable, biblical instruction needs to be central.

- A hand-up approach to integral mission is needed to restore dignity and instil resilience (Corbett \& Fikkert 2012:247-249). Therefore, 1 Corinthians 12's principles of mentorship need to be entrenched. Pastors and Christian leaders need to become mentor disciples and Social Enablement as Mission projects need facilitators who understand and are passionate about the gospel.

- Poor people need to understand that they have been made in the image of God. They need to understand who God is and what he has done for them. Biblical stewardship needs to be better explained and people need to learn how to live a life of sharing and helping one another. The reaction to this approach will lead to evangelism, mentorship type of discipleship and stewardship (Corbett \& Fikkert 2014c: Session 6). Only when poor people realise this, they will develop the self-confidence and self-worth that empowers sustainable transformation and Christian resilience only when they realise this, will they develop the self-confidence and self-worth that enables transformation (Stubbs 2020:141-142).

\section{Recommendations}

\section{Social Enablement as Mission as a possible contributing} response to the biblical education crisis

This study has highlighted the urgent need for appropriate (accessible, contextual [Fikkert \& Mask 2015:29-33], affordable, integral mission based) biblical Christian leader education. When there is a misunderstanding of the gospel of Jesus Christ, people become disillusioned and, as discussed earlier, they get confused between the difference between physical wealth and health, and spiritual riches. When this becomes mixed up with syncretism, it becomes even more dangerous (Mbewe 2013:n.p.). These worldviews prevent people from having self-worth, confidence and becoming self-sufficient. As discussed, in a similar way, a lack of Christian mentorship in Social Enablement as Mission can lead to despondency and result in unsustainability (Stubbs 2020:158). Furthermore, Christian leaders, especially pastors, need to be discipling mentors. One can see the fruits and church growth of pastors who are mentors compared to those who serve their own self-interests. ${ }^{7}$

A proposed solution to this problem is to incorporate Social Enablement as Mission into the new National

7.An example is the work of the mentor, Reverend Herens Nkoana at Ramotse Reformed Church http://ramotsereformed.co.za/.
Qualification Framework (NQF) Level 2 and 5 Christian Religious Professional (South African Qualifications Authority [SAQA] 2017:2) qualifications. Already these qualifications are practical, accessible and affordable. When they are presented by theological colleges, they provide students with a biblical-based education. If those same students learn Social Enablement as Mission, as an approach to their ministries, poor rural and independent churches in South Africa and Social Enablement as Mission type projects will become better equipped to proclaim and demonstrate the gospel.

\section{Social Enablement as Mission as a humanitarian response to a crisis}

Social Enablement as Mission could be used in a humanitarian action situation (like COVID-19) where poor people are empowered (ultimately by the Holy Spirit working through the proclamation and demonstration of the gospel) (Fikkert \& Mask 2015:29) to look to Christ for their hope in two ways: (1) understanding the hope that the gospel offers salvation from sin and eternal life; and (2) faith in God's provision.

A proposed Social Enablement as Mission reaction to a humanitarian crisis such as COVID-19 could be to: (1) Provide some staple foods, for example, some mielie-meal, along with accessible training material that teaches people how to grow food (see ' $Z$ fold Produce your own food rural' [Ferreira \& Stubbs 2020b]), a gospel tract (see 'Zulu Tract' [Ferreira \& Stubbs 2020c]) and information about the crisis (see 'Corona Zulu' [Ferreira \& Stubbs 2020a]). (2) Tell each recipient that you will return in $2-3$ weeks and evaluate what they have done with the information from the pamphlets. If they have dug a trench, produced or sourced some compost, prepared some mulching, prepared a seedling dish, built a chicken roost and can answer some questions in a way that they demonstrate that they understand the contents of the tract and demonstrate that they are willing to do something towards the transformation of their own lives, they can be given some tools to help them do so. In this case, those who attempt to do these things could be rewarded with a variety of good quality vegetable seeds, two hens and a rooster, a Bible in their language of choice and an African Honey Bee Catechism (Korevaar, Miskin \& Stubbs 2017). These would not only serve as tools to survive, but they would contribute towards people transforming their worldview and thereby enable them to flourish from a Christian perspective. In other words, they would change for the good and, through their evangelism and witness, their families would change, their communities would change, and they all would become more resilient to the hardships of life. A critical aspect of this solution would be to ensure ongoing Christian mentorship for those whose lives change.

\section{Acknowledgements}

We thank the Thembalethu Centre in Kwamhlanga and African Honey Bee in uMfolozi and our appreciation and gratitude to all the families that participated in the survey. 


\section{Competing interests}

The authors have declared that no competing interest exist.

\section{Authors' contributions}

All authors contributed equally to this work.

\section{Ethical consideration}

This article followed all ethical standards for a research without direct contact with human or animal subjects.

\section{Funding information}

This research received no specific grant from any funding agency in the public, commercial or not-for-profit sectors.

\section{Data availability statement}

The authors confirm that the data supporting the findings of this study are available within the article.

\section{Disclaimer}

The views and opinions expressed in this article are those of the authors and do not necessarily reflect the official policy of any affiliated agency of the authors.

\section{References}

Awendila, K., 2020, 'God is not a genie', Christian Today, viewed 23 July 2020, from https://bit.ly/2OPylBW.

Barrett, A., 2013, Asset-Based Community Development: A theological reflection, Church Urban Fund, Birmingham.

Buys, P., 2020, 'Building resilient communities in the midst of shame, guilt, fear witchcraft, and HIV/AIDS', KOERS - Bulletin for Christian Scholarship 85(1), viewed 06 July 2020, from, https://doi.org/10.19108/KOERS.85.1.2464

Buys, P. \& Stubbs, G., 2019, 'Honey from the rock - Principles of integral mission learnt from beekeeping development in the uMfolozi area of South Africa', In die Skriflig/In Luce Verbi 53(1), viewed 06 July 2020, from https://doi.org/10.4102/ ids.v53i1.2454

Centers for Disease Control and Prevention, 2020, Centers for Disease Control and Prevention, National Center for Immunization and Respiratory Diseases, viewed 06 July 2020, from https://www.cdc.gov/flu/pandemic-resources/1918 pandemic-h1n1.html.

Corbett, S. \& Fikkert, B., 2012, When helping hurts: How to alleviate poverty without hurting the poor ... and yourself, Moody, Chicago, IL.

Corbett, S. \& Fikkert, B., 2014a, Reconsidering the meaning of poverty, Short film series, Session 1, The Chalmers Center, Lookout Mountain, GA.

Corbett, S. \& Fikkert, B., 2014b, When helping hurts, Short film series, Session 5, The Chalmers Center, Lookout Mountain, GA.

Corbett, S. \& Fikkert, B., 2014c, When helping hurts, Short film series, Session 6, The Chalmers Center, Lookout Mountain, GA.

Ferreira, E. \& Stubbs, G., 2020a, Corona Zulu, Pretoria, viewed 06 July 2020, from https://africanhoneybee.co.za/pdf/Corona\%20Zulu-new.pdf.

Ferreira, E. \& Stubbs, G., 2020b, Z fold produce your own food rural, Pretoria, viewed 06 July 2020, from https://africanhoneybee.co.za/pdf/Z\%20fold $\% 20$ Produce $\% 20$ your $\% 20$ own $\% 20$ food $\% 20$ rural.pdf.

Ferreira, E. \& Stubbs, G., 2020c, Zulu tract, Pretoria, viewed 06 July 2020, from https:// africanhoneybee.co.za/pdf/Zulu\%20Tract.pdf.

Fikkert, B. \& Mask, R., 2015, From dependence to dignity, Kindle edn, Zondervan.

Georges, J., 2016, The 3D Gospel: Ministry in guilt, shame, and fear cultures, Timē, Charlottesville, VA.

Germann, S., 2005, 'I am a hero - Orphans in child-headed households and resilience', Commonwealth Youth and Development 3(2), 39-53.

Goheen, M., 2011, A light to the nations: The missional church and the biblical story, Baker, Ada, OK.

Gould, G. \& Pyle, W., 1896, Anomalies and curiosities of medicine, Charlottesville VA, viewed 20 July 2020, from https://web.archive.org/web/20080912125758/ http://etext.lib.virginia.edu/toc/modeng/public/GouAnom.html.
Granlund, S. \& Hochfeld, T., 2020, 'That child support grant gives me powers' Exploring social and relational aspects of cash transfers in South Africa in times of livelihood change', The Journal of Development Studies 56(6), 1230-1244. https:// doi.org/10.1080/00220388.2019.1650170

Heidelberg Catechism, 2015, Canadian and American Reformed Churches, Grand Rapids, MI, viewed 20 July 2020, from https://canrc.org/heidelberg-catechism.

Helm, P., 1998, 'John Calvin, the Sensus Divinitatis, and the noetic effects of $\sin ^{\prime}$ International Journal for Philosophy of Religion 43(2), 87-107. https://doi. org/10.1023/A:1003174629151

Heywood, M., 2020, 'Malnutrition, health services and democracy: The responsibility to speak out', Maverick Citizen, 26 May, viewed 21 July 2020, from https://bit. ly/3jqcTRQ.

Jansen, A., 2017, Heart, hands \& voices: God's mission: integrating word and deeds, Buijten \& Schipperheijn, Amsterdam.

Jeffery, A., 2020, The ten-year lockdown, with worse still to come, ed. F. Cronje, The South African Institute of Race Relations, Johannesburg.

Johnson, J., 2012, We are not the hero: A missionary's guide for sharing Christ, not a culture of dependency, Deep River Books, Sisters, OR.

Korevaar, J., 2020, Data analysis from resilience to COVID-19, Khanyisani Trust, Pretoria.

Korevaar, J., Miskin, A. \& Stubbs, G., 2017, AHB catechism, Pretoria, viewed 22 July 2020, from https://africanhoneybee.co.za/pdf/AHB-Catechism-new.pdf.

Laininen, E., 2019, 'Transforming our worldview towards a sustainable future', in J. Cook (ed.), Sustainability, human well-being, and the future of education, pp. 161-200, Palgrave Macmillan, London.

Lederer, E., 2020, 'COVID-19 is worst global crisis since World War II - UN chief', Africanews, viewed 22 July 2020, from http://www.africanews.com/ amp/2020/04/01/covid-19-is-worst-global-crisis-since-world-war-ii-un-chief/.

Leshota, P., 2015, From dependence to interdependence: Towards a practical theology of disability, viewed 22 July 2020, from https://doi.org/10.4102/hts.v71i2.2680

Lumumba, P., 2013, Corruption in Africa. Key note speech at the 3rd anti-corruption convention in Kampala, Uganda, Kampala, viewed 18 July 2020, from https:// www.youtube.com/watch?v=4cbEuwqKKqE.

Magezi, V., 2007, 'Pastoral counselling: Towards a diagnostic and interpretational approach in Africa', In die Skriflig 41(4), 655-672. https://doi.org/10.4102/ids. v41i4.325

Marumo, P., 2016, 'Christianity and African traditional religion in dialogue; An ecological future for Africa', PhD thesis, North-West University, Mahikeng.

Mashau, T., 2012, 'A reformed perspective on taking mission and missiology to the heart of theological training', In die Skriflig/In Luce Verbi 46(2), a64. https://doi. org/10.4102/ids.v46i2.64

Mathema, Z., 2007, 'The African worldview: A serious challenge to Christian worldview', Ministry 79(10), 5-8.

Mbetwa, C., 2018, Why Africa is poor, Merina, Chingola.

Mbewe, C., 2013, Are we preachers or witch doctors?, viewed 24 July 2020, from https://bit.ly/3htq9DD.

Mbiti, J., 1969, African religions and philosophy, Heinemann, London.

Mbiti, J., 1970, Concepts of God in Africa, Heinemann, London.

Mbuvi, A., 2002, 'African Theology from the perspective of honor and shame', in H.M. Conn, M. Ortiz \& S.S. Baker (eds.), The urban face of mission; Ministering the Gospel in a diverse and changing world, pp. 279-339, Baker, Phillipsburg, NJ.

Miller, D. \& Guthrie, S., 2001, Discipling nations: The power of truth to transform cultures, Youth with a Mission, Edmonds, WA.

Mkize, V., Masuabi, Q. \& Ntsaluba, G., 2020, 'Covid-19 death storm is here: Doctors have to choose, funeral parlours at full capacity, and experts say this could have been prevented', City Press, 12 July.

Morifi, M., 2020, 'SA's hunger is everyone's problem', Food For Mzansi, 05 May, viewed 25 July 2020, from https://www.foodformzansi.co.za/sas-hunger-iseveryones-problem/.

Myers, A., 1987, Peter second letter of - The Eerdmans Bible dictionary, Eerdmans, Grand Rapids, MI.

Newbigin, L., 2017, Newbigin Resourses Website, viewed 01 July 2019, from https:// newbiginresources.org/.

Nyirongo, L., 1997, The gods of Africa or the God of the Bible? African traditional religion in biblical perspective, North-West University, Potchefstroom.

Patel, L., Sadie, Y., Graham, V., Delany, A. \& Baldry, K., 2014, Voting behaviour and the influence of social protection, Survey, Centre for Social Development in Africa and University of Johannesburg, Johannesburg.

Paul-Choudhury, S., 2019, 'Tomorrow's Gods: What is the future of religion?', BBC Future, viewed 22 July 2020, from https://bbc.in/2WKL1ye.

Qureshi, A., 2016, Ebola virus disease: From origin to outbreak, Google Books, Academic Press, Cambridge, MA.

Reese, R., 2012, Roots \& remedies: Of the dependency syndrome in world missions, William Carey Library, Pasadena, CA.

Riopel, L., 2020, Resilience skills, factors and strategies of the resilient person, viewed 20 July 2020, from https://positivepsychology.com/resilience-skills/.

Schwartz, G., 2007, Overcoming unhealthy dependency in the Christian movement, a compendium, Author House, Bloomington, IN.

Setiloane, G., 1986, African theology, Skotaville Publishers, Johannesburg. 
Somdyala, K., 2019, 'Bogus pastors: Ramaphosa concerned by "questionable practices surging to the fore"', 19 February, viewed 25 July 2020, from https:// practices surging
bit.ly/2E96Yk7.

South African Qualifications Authority (SAQA), 2017, Registered qualification: Occupational certificate: Christian religious professional, South African Qualifications Authority, Pretoria.

Stark, R., 1996, The rise of Christianity, Princeton University Press, Princetown, CA.

Stats SA, 2004, Census 2001: Primary tables: Census ' 96 and 2001 compared, Statistics South Africa, Pretoria, viewed 24 July 2020, from http://www.statssa.gov.za/ census/census_2001/primary_tables/RSAPrimary.pdf.

Stats SA., 2011, Statistics South Africa, viewed 13 July 2020, from http://www.statssa. gov.za/.

Stubbs, G., 2020, 'Honey from the Rock. Poverty alleviation from a missio De perspective presented as a missiological case study of Integral Mission through
the African Honey Bee project in the uMfolozi area of South Africa', PhD thesis, North-West University, Potchefstroom.

Turaki, Y., 1999, Christianity and African Gods (A method in theology), North West University, Potchefstroom.

Turaki, Y., 2012, The Trinity of sin, Zondervan, Grand Rapids, MI.

Van Biema, D. \& Chu, J., 2006, 'Does God want you to be rich?', Time Magazine, viewed 25 July 2020 , from https://bit.ly/2ZPGsEQ.
Van der Walt, B., 1991, A Christian worldview and Christian Higher Education for Africa, North West University, Potchefstroom.

Van der Walt, B., 1999, 'Kultuur, lewensvisie en ontwikkeling: 'n Ontmaskering van die gode van die gode van onderontwikkelde Afrika en die oorontwikkelde Weste', PU vir CHO, Potchefstroom. (Reeks F2: Brosjures, 76[F2]).

Van der Walt, B., 2003, Understanding and rebuilding Africa; from desperation today towards expectation for tomorrow, Institute of Contemporary Christianity in Africa, Potchefstroom.

Van Rooy, J., 1999, 'The Christian gospel as a basis for escape from poverty in Africa', In die Skriflig 22(2), 235-253. https://doi.org/10.4102/ids.v33i2.626

Webb, C. \& Vally, N., 2020, 'South Africa has raised social grants: Why this shouldn't be a stop-gap measure', The Conversation Africa, viewed 26 July 2020, from https:// bit.ly/32UzfFx.

Weingärtner, L., Pichon, F. \& Simonet, C., 2017, How self-help groups strengthen resilience, Tearfund - Overseas Development Institute, London.

Wright, C., 2010, The mission of God's people: A biblical theology of the church's mission, Zondervan, Grand Rapids, MI.

Wright, N., 2008, Surprised by hope: Rethinking heaven, the resurrection, and the mission of the church, Zondervan, Grand Rapids, MI.

Zaspel, F., 2020, The free offer of the Gospel, New York, NY, viewed 25 July 2020, from https://www.thegospelcoalition.org/essay/free-offer-gospel/. 


\section{Appendix 1}

\section{Questionnaire}

Completed by:

Date:

Cell:

\section{QUESTIONNAIRE}

Surname

ID number
First name

Cell phone

Address

Number of people in household

How many have a job? How many receive Government grants?

How many lost jobs due to COVID-19 Have you received food parcels? (Y) (N) If yes, from who?

Do you have other Income generating activities? $(\mathrm{Y})(\mathrm{N}) \quad$ Is anyone in your household: [1] Growing vegetables? (Y) (N)

[2] Producing eggs? (Y) (N) [3] Producing chickens for meat? (Y) (N) [4] Producing any other food? (Y) (N)

If yes, describe

Do you believe that the Bible is the word of God? (Y) (N) What is the main message of the Bible?

Do you pray? $(\mathrm{Y})(\mathrm{N})$ If so, how often? (Regularly) (Occasionally) (Sundays) Do you pray about the corona virus? ( $\mathrm{Y})(\mathrm{N})$ What are some things you pray about?

Do you think that God has sent the coronavirus? Why/why not? (Y) (N)

How do you think God works to care and provide for us today?

Do you think God is angry with our world or pleased with us? (Y) (N) Please explain

Do you believe that you can be a Christian and also believe in ancestral spirits? (Y) (N) Please explain

Do you believe in the healing ability of traditional healers? (Y) (N) Do you think that traditional healers can cure the corona virus? (Y) (N) Do you think social distancing can stop the spread of the corona virus? (Y) (N) If so, what is your main motivation for social distancing during COVID-19? (A) so you don't die from the virus, or (B) so you don't spread the virus Do you think we must help our neighbours or display African ubuntu in this time? (Y) (N) Please explain 
How can we be sure that God loves and cares for us? (Y) (N) Please explain

Signatures: Respondent Surveyor

Concept phrases: resilience during COVID-19; community resilience; biblical resilience; integral mission as a method for social development; social enablement as a method of evangelism and discipleship; coping during a crisis; a biblical response to a pandemic; the problems of prosperity gospel and syncretism; need for biblical training; need for pastoral training; the importance of mentorship to ensure sustainability. 